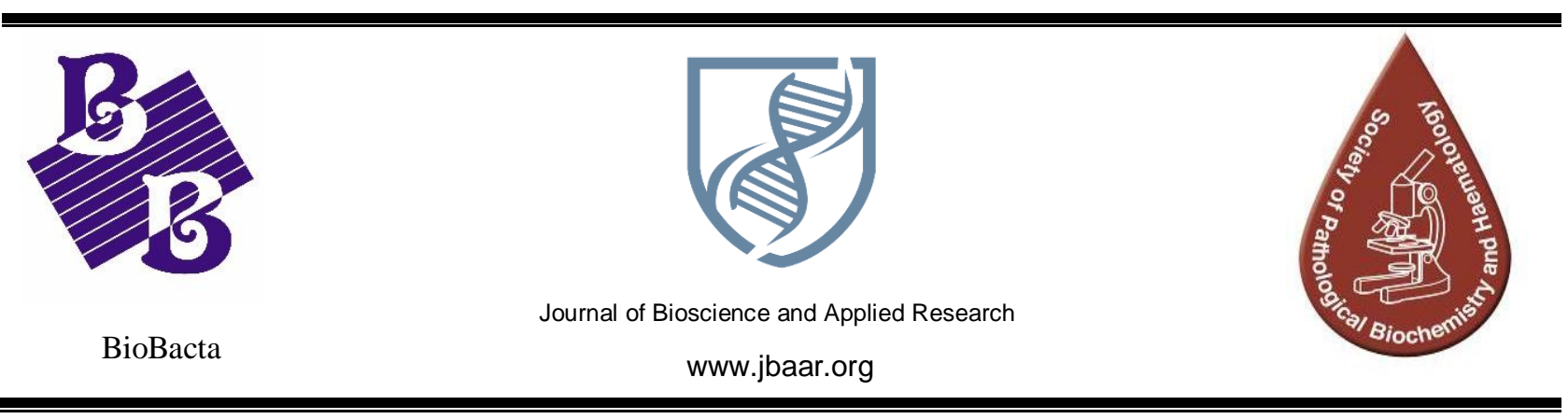

\title{
Comparative effect of extracts of Blighia sapida (Sapindaceae) from three regions on the biochemical parameters of hypertensive rats
}

\section{Yao Honoré N'GUESSAN*1,2, Wawa Justine TIEKPA ${ }^{3}$, Mandé Ryta Adélaïde DOUE ${ }^{2}$, Cassime TIEMOKO ${ }^{2}$, Chérif Moustapha KARAMOKO², Alain Dit Phillippe BIDIE ${ }^{1,2}$, Daouda KONE'.}

\author{
${ }^{1}$ African Center of Excellence on Climate Change, Biodiversity, and Sustainable Agriculture, Félix Houphouet-Boigny \\ University, Abidjan, Ivory Coast, 22 BP 582 Abidjan 22, Ivory Coast. \\ 2 Pharmacodynamics-Biochemical Laboratory, UFR Biosciences, Félix Houphouet-Boigny University, Abidjan, Ivory \\ Coast, 22 BP 582 Abidjan 22, Ivory Coast. \\ ${ }^{3}$ Péliforo Gon Coulibaly University, BP 1328 Korhogo, Ivory Coast. \\ * Corresponding author, Tel: (+225) 09144337; E-mail: nyaohonore@ gmail.com
}

Received 1/1/2020; Accepted 23/3/2020

DOI: $10.21608 /$ jbaar.2020.116129

\begin{abstract}
Blighia sapida is a plant with many therapeutic virtues. In Ivory Coast, this plant is widespread in several regions with different climatic conditions. Our study aims to compare the effects of aqueous extracts of Blighia sapida harvested in three Ivorian regions on the biochemical parameters of rats made hypertensive by a fructose diet. Rats (20) were fed a high fructose diet (70\% fructose, 10\% fat, $20 \%$ protein) for 30 days. Then blood pressure was measured from an armband to the tail of the rats. Finally, biochemical and lipid parameters were measured before and after the fructose-enriched diet. All rats fed the high-fructose diet had similar rates of hypertension $(\mathrm{SBP}=160.0 \pm 0.07 \mathrm{mmHg}$; $\mathrm{DBP}=141.5 \pm 1.21 \mathrm{mmHg} ; \mathrm{HR}=325.7 \pm 1.52$ beats/min) and a change in dosing parameters. Aqueous extracts of Blighia sapida from Adzopé (EAA) and Korhogo (EAK) administered to hypertensive rats normalized the previously increased cardiovascular, biochemical, and lipid parameters compared to control rats (healthy and untreated diseased rats). However, the aqueous extract of Blighia sapida of Adzopé (EAA) showed the best effects on hypertension compared to the aqueous extract of Blighia sapida of Korhogo (EAK). Indeed, the more humid the region and the climate, the more effective the extract is. The regulating effect of aqueous extracts of Blighia sapida on blood pressure, therefore, differs from one region to another with different climatic conditions. This would explain its use in traditional medicine in certain climatic zones compared to others where its therapeutic effects would be unknown because less. Adzopé would, therefore, be the best region where Blighia sapida should be harvested for the optimal treatment of high blood pressure.
\end{abstract}

Keywords: Blighia sapida, biochemical parameters, hypertension, Sapindaceae. 


\section{Introduction}

The use of plants for therapeutic purposes has been known by our ancestors and parents for a very long time (Mamyrbekova-Békro et al., 2011). In recent decades, $70-95 \%$ of the world's population has been using medicinal plants for primary care due to a lack of access to the drugs prescribed by modern medicine but also because plants have been able to demonstrate real efficacy (Selles, 2012). Thus, the African pharmacopeia, which aims to develop recipes or formulas that only traditional therapists have the secret, deserves to be highlighted by scientific support given the increasingly considerable fringe of the population that uses it.

To this end, several investigations have been carried out to provide a scientific approach to the use of this traditional medicine. This led to the discovery of a large number of medicinal plants, including Blighia sapida. Blighia sapida is a medium-sized tree of the Sapindaceae family native to West Africa and cultivated in tropical regions for its edible fruit. In Nigeria, the bark, stem, and leaves of Blighia sapida are used in the treatment of fever, malaria, hemorrhage, dysentery, yellow fever, diabetes, constipation, prevention of degenerative diseases, and reduction of cancer and cardiovascular disease (Okwu et al., 2006; Dossou et al., 2014). In Ghana, root bark is a traditional antibiotic used mainly for the treatment of diarrhea (Antwi et al., 2009). In Côte d'Ivoire, Blighia sapida is widespread in several regions with different climatic conditions and its bark is used to treat high blood pressure.

The objective of this work is to compare the effect of aqueous extracts of Blighia sapida from three Ivorian regions on the biochemical parameters of rats made hypertensive by fructose.

\section{Materials and methods}

\subsection{Materials}

\subsubsection{Plant material}

The plant material consists of Blighia sapida bark. The bark was harvested in the forest region of Adzopé (South-East) and in the savannah region in Korhogo (North).

\subsubsection{Animal material}

Rats of the species Rattus norvegicus strain Wistar were used for this study. They were provided by the Animal Physiology Laboratory of the Biosciences UFR of the Félix Houphouët-Boigny University (Abidjan, Côte d'Ivoire). The animals kept in plastic cages with stainless steel covers were acclimatized in the animal house of the Ecole Normale Supérieure (ENS) (Abidjan, Côte d'Ivoire). The cages contained a litter of wood shavings renewed every two days throughout the experiment. The experiments were carried out according to a good practice guide to the administration of substances and removal of blood, including routes and volumes with rules and guidelines established for the care of laboratory animals (Diehl et al., 2001).

\subsection{Methods}

\subsubsection{Preparation of extracts}

The bark of Blighia sapida harvested was washed and cut into small pieces. They were dried in the shade of the sun at room temperature. The dried bark was made into a fine powder and the aqueous extract was obtained according to the method used by Talbi et al. (2014). According to this method, $300 \mathrm{~g}$ of Blighia sapida powder was mixed with $3 \mathrm{~L}$ of distilled water. The aqueous mixture was stirred for $48 \mathrm{~h}$ at $80^{\circ} \mathrm{C}$ using a magnetic stirrer type IKAMAG RCT. The homogenate obtained was filtered twice successively on cotton wool and then on Büchner with Wattman paper. The filtrate was evaporated under reduced pressure at a temperature of $50{ }^{\circ} \mathrm{C}$ using a BÜCHI rotary evaporator. The dry evaporate was recovered in powder form, thus constituting the total aqueous extract used for any further work.

\subsubsection{The qualitative and quantitative study of secondary metabolites}

Phytochemical screening was carried out according to the methods used by Bidié et al. (2011) and Coulibaly et al. (2017). These studies were based on staining tests, precipitation tests, and ultravioletlight observations. 
Quantification of the content of secondary metabolites in Blighia sapida extracts was carried out using spectrophotometric methods applied by Fadili et al. (2017) and Evenamede et al. (2017). Thus, the total polyphenol content of the extracts was determined by the Folin-Ciocalteu method and the aluminium trichloride $\mathrm{AlCl}_{3}$ method was adopted for the determination of total flavonoids.

\subsubsection{Induction of hypertension}

The rats (24) were divided into two lots, lot G1 of four rats and a second lot G2 of twenty rats. Lot (G1) representing the control group was fed pellets and distilled water, and test lot G2 received the fructose diet for 30 days. During this period, cardiovascular and biochemical parameters were measured every five (05) days until the end of induction. At the end of the 30 days, the animals were left untreated and observed for five (05) days and the cardiovascular and biochemical parameters were measured again.

\subsubsection{Treatment of animals rendered hypertensive}

After the determination of hypertension, the animals in test batch G2 were subdivided into batches of four rats each (G2' to G6) and treated for seven (07) as follows :

G1: control rats;

G2' sick control rats;

G3: untreated diseased control rats;

G4: rats treated with Adzopé aqueous extract (EAA) at a dose of $400 \mathrm{mg} / \mathrm{Kg}$. bw per day;
G5: rats treated with Korhogo aqueous extract (EAK) at $400 \mathrm{mg} / \mathrm{Kg}$. bw per day;

G6: rats treated with nifedipine (NIFE) at a dose of $10 \mathrm{mg} / \mathrm{Kg}$. bw per day.

At the end of treatment, biochemical parameters such as transaminases (ASAT and ALAT), urea, creatinine, lactate dehydrogenase, and lipid profile were determined using a Cobas Integras automaton.

\section{Statistical analysis}

The recorded data were processed using GraphPad software version 7. For each variable, the mean (M) and the standard deviation of the mean (SD) were calculated. The results of the different groups were compared using the analysis of variance (ANOVA) of Turkey and Dunnett. The level of statistical significance of the results was set at $p<0.05$.

\section{Results}

\subsection{Result of the spectrophotometric determination of total polyphenols and flavonoids}

The determination of total polyphenols in aqueous extracts of Blighia sapida gave the results presented in Table I. These results show that the highest content $(13.77 \pm 0.76 \mathrm{mg} \mathrm{EAG} / \mathrm{g})$ was found with the aqueous extract from the Adzopé region followed by the aqueous extract from the Korhogo region (11.11 $\pm 1.01 \mathrm{mg} \mathrm{EAG} / \mathrm{g})$. EAA also recorded the highest total flavonoid content $(3.76 \pm$ $0.00 \mathrm{mg} \mathrm{EQ} / \mathrm{g})$ followed by EAK $(3.38 \pm 0.04 \mathrm{mg}$ $\mathrm{EQ} / \mathrm{g}$ ). The concentration of total polyphenols and flavonoids, therefore, differed from region to region.

Table I: Result of the determination of total polyphenols and flavonoids of aqueous extracts

\begin{tabular}{|c|c|c|}
\hline Extracts & EAA & EAK \\
\hline Polyphenols $(\mathrm{mg} \mathrm{EAG/g)}$ & $\mathbf{1 3 . 7 7} \pm \mathbf{0 . 7 6}$ & $11.11 \pm 1.01$ \\
\hline Flavonoids $(\mathrm{mg} \mathrm{EQ/g)}$ & $3.76 \pm 0.15$ & $3.38 \pm 0.04$ \\
\hline
\end{tabular}




\subsection{Effect of fructose on cardiovascular parameters}

Ingestion of the fructose diet for 30 days by $\mathrm{G} 2$ rats caused a very significant increase in cardiovascular parameters. During this permanent increase in blood pressure (SBP from $122.2 \pm 1.27 \mathrm{mmHg}$ to $160.0 \pm$ $0.07 \mathrm{mmHg}$; DBP from $102.7 \pm 3.11 \mathrm{mmHg}$ to $141.5 \pm 1.21 \mathrm{mmHg}$ and cardiac pool (HR from $239.7 \pm 1.15$ beats $/ \mathrm{min}$ to $325.7 \pm 1.52$ beats $/ \mathrm{min}$ ), the results of the assay of certain biochemical parameters showed a very significant increase in urea, creatinine, transaminases (AST and ALT) and LDH in rats fed the fructose diet.

\subsection{Effect of aqueous extracts of Blighia sapida on serum markers of kidney, heart, and liver during treatment}

Figures 1; 2 and 3 show the results of the pharmacological effect of aqueous extracts of Blighia sapida on serum markers of the kidney, heart, and liver in fructose-hypertensive rats. These figures show that excessive ingestion of the fructose diet significantly increased serum levels of urea (A) (from $0.44 \pm 0.03 \mathrm{mmol} / \mathrm{L}$ to $2.11 \pm 0.11 \mathrm{mmol} / \mathrm{L}$ ), creatinine (B) (from 23,08 $\pm 1.97 \mu \mathrm{mol} / \mathrm{L}$ to $63.66 \pm$ $3.60 \mu \mathrm{mol} / \mathrm{L})$, ASAT (C) $(156.2 \pm 1.04 \mathrm{U} / \mathrm{L}$ to 200.0 $\pm 0.04 \mathrm{U} / \mathrm{L})$, ALAT $(\mathbf{D})(72.2 \pm 3.01 \mathrm{U} / \mathrm{L}$ to $127.5 \pm$ $3.34 \mathrm{U} / \mathrm{L})$ and $\mathrm{LDH}(\mathbf{E})(184.5 \pm 4.45 \mathrm{IU}$ to $275.7 \pm$ 5.45 IU). Treatment of hypertensive rats with 400 $\mathrm{mg} / \mathrm{kg}$ bw of various aqueous extracts of Blighia sapida significantly decreased the increase in serum levels of these serum markers of the kidney, heart, and, liver caused by the fructose diet. The aqueous extract from the Adzopé region showed the best effects on biochemical disorders caused by fructose followed by the aqueous extract from Korhogo (Figures 1; 2 and 3). The effects of Blighia sapida extracts were contrasted from one region to another due to differences in soils, vegetation and thus climate.

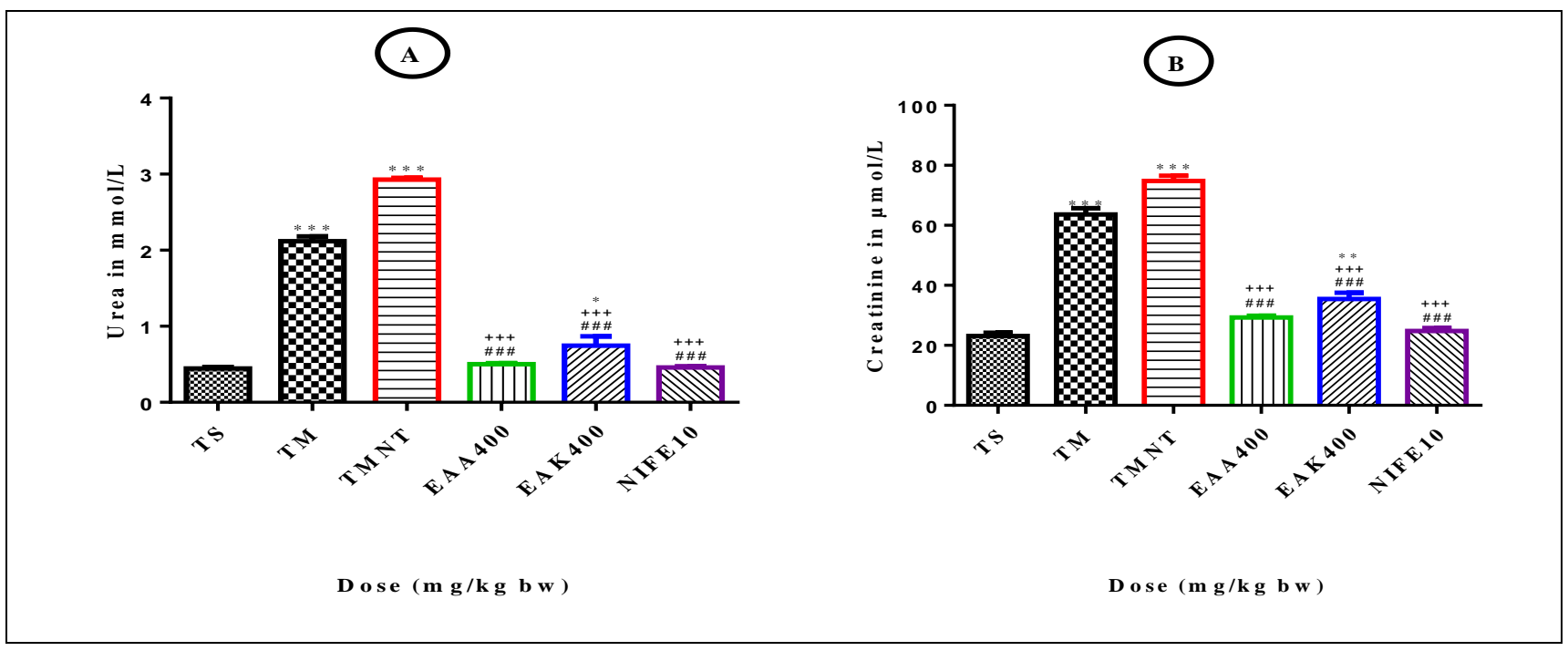

Figure 1: Comparison of the pharmacological effects of EAA and EAK extracts on serum urea (A) and creatinine $(\mathbf{B})$ values in hypertensive rats.

Each bar represents the average \pm SEM. $* * *$, significant difference from the normotensive control lot at $\mathrm{p}<0.001 ; *$ significant difference from the control lot at $\mathrm{p}<0.05$; \#\#\#, a significant difference from the hypertensive lot (TM) at $\mathrm{p}<0.001 ;+++$, a significant difference from the untreated diseased lot (TMNT) at $\mathrm{p}<0.001$; --- significant difference from the Adzopé Aqueous Extract (EAA) lot

TS: normotensive control lot; TM: hypertensive lot; TMNT: untreated diseased lot; EAA 400: lot treated with Adzopé Aqueous Extract at $400 \mathrm{mg} / \mathrm{kg}$ bw; EAK 400: lot treated with Korhogo Aqueous Extract at $400 \mathrm{mg} / \mathrm{kg}$ bw. 


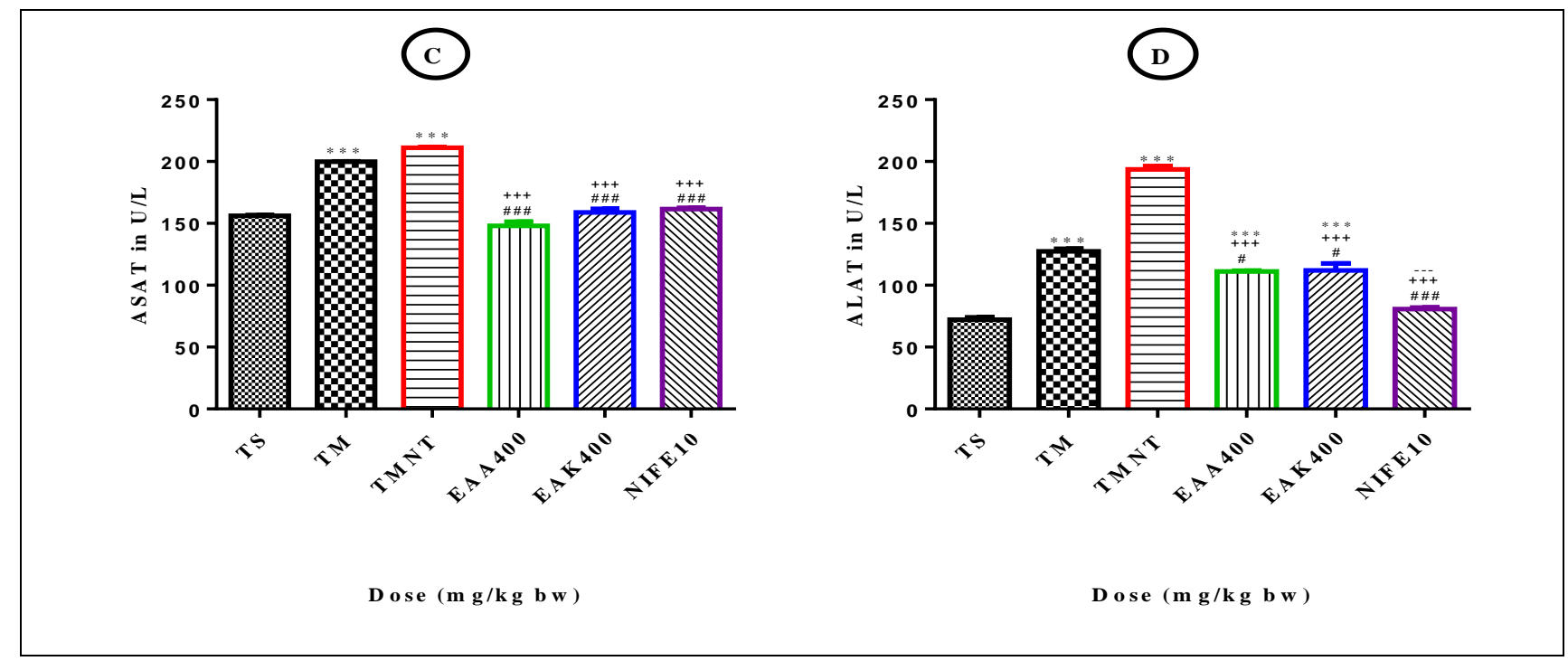

Figure 2: Comparison of the pharmacological effects of EAA and EAK extracts on serum transaminase values: AST (C) and ALT (D) in hypertensive rats.

Each bar represents the average \pm SEM. $* * *$, significant difference from the normotensive control lot at $\mathrm{p}<0.001 ; *$ significant difference from the control lot at $\mathrm{p}<0.05$; \#\#\#, a significant difference from the hypertensive lot (TM) at $\mathrm{p}<0.001$; +++, a significant difference from the untreated diseased lot (TMNT) at $p<0.001$; --- significant difference from the Adzopé Aqueous Extract (EAA) lot

TS: normotensive control lot; TM: hypertensive lot; TMNT: untreated diseased lot; EAA 400: lot treated with Adzopé Aqueous Extract at $400 \mathrm{mg} / \mathrm{kg}$ bw; EAK 400: lot treated with Korhogo Aqueous Extract at $400 \mathrm{mg} / \mathrm{kg}$ bw.

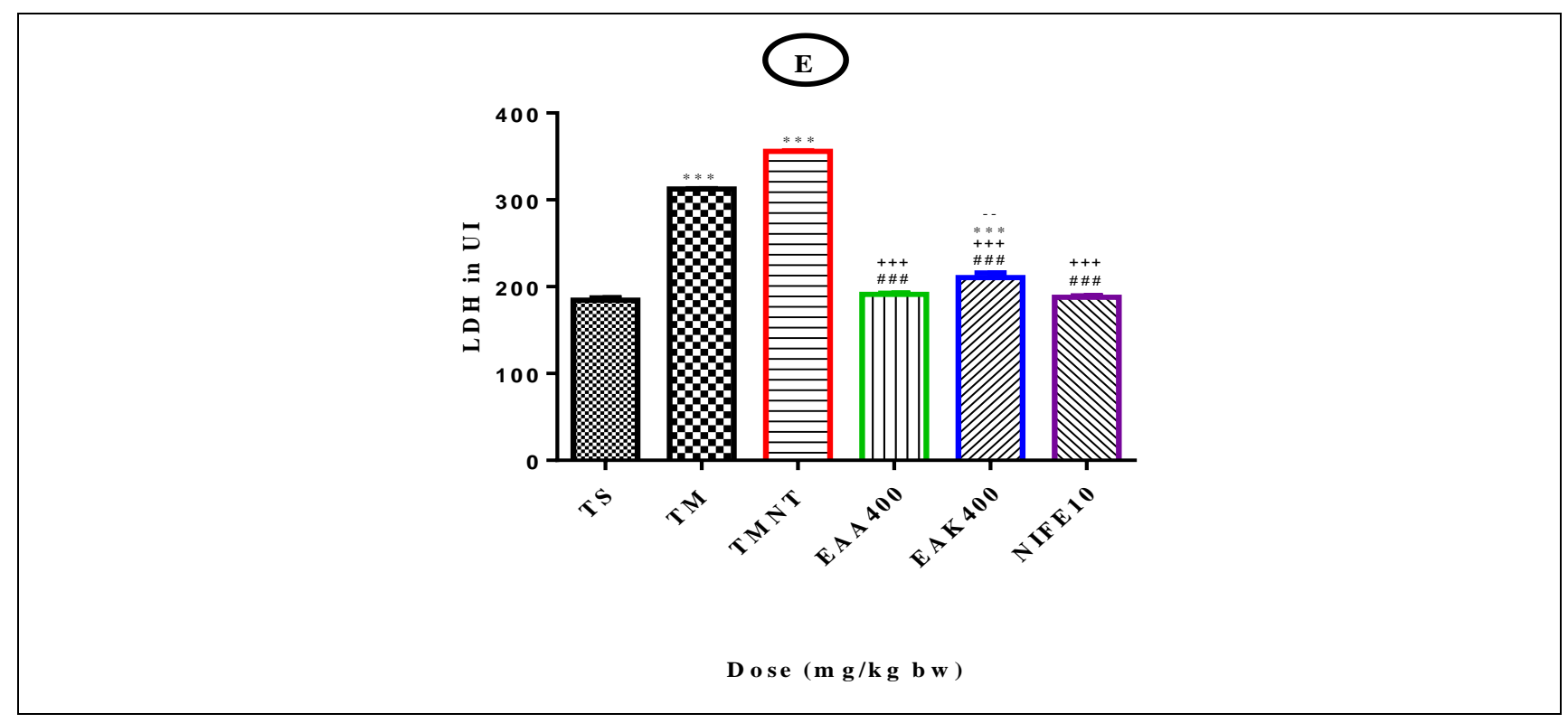

Figure 3: Comparison of pharmacological effects of EAA and EAK extracts on serum lactate dehydrogenase (LDH) values (E)

Each bar represents the average \pm SEM. $* * *$, significant difference from the normotensive control lot at $\mathrm{p}<0.001 ; *$ significant difference from the control lot at $\mathrm{p}<0.05$; \#\#\#, a significant difference from the hypertensive lot (TM) at $\mathrm{p}<0.001$; +++, a significant difference from the untreated diseased lot (TMNT) at $\mathrm{p}<0.001$; --- significant difference from the Adzopé Aqueous Extract (EAA) lot

TS: normotensive control lot; TM: hypertensive lot; TMNT: untreated diseased lot; EAA 400: lot treated with Adzopé Aqueous Extract at $400 \mathrm{mg} / \mathrm{kg}$ bw; EAK 400: lot treated with Korhogo Aqueous Extract at $400 \mathrm{mg} / \mathrm{kg}$ bw. 
3.4. Effect of aqueous extracts of Blighia sapida on the lipid profile of hypertensive rats

This study showed that consumption of fructose resulted in a significant increase in serum triglyceride (TG), low-density lipoprotein (LDL), total cholesterol (CHOL), and a significant decrease in high-density lipoprotein (HDL) compared to healthy and untreated diseased controls. Figures 4 and 5 show that the administration of aqueous extracts of Blighia sapida resulted in a very significant reduction in serum concentrations of TG
(F), CHOL (G), LDL (I) and a significant increase in serum HDL (H) compared to untreated hypertensive rats. These findings were best seen at $400 \mathrm{mg} / \mathrm{kg}$ bw with EAA followed by EAK, which had the least effect on lipid disturbances induced by the fructose diet. The effect of aqueous extracts on the lipid profile of hypertensive rats was thus different from the Adzopé region to the Korhogo region and thus from the sub-equatorial (southern) to the Sudanian (northern) climate.

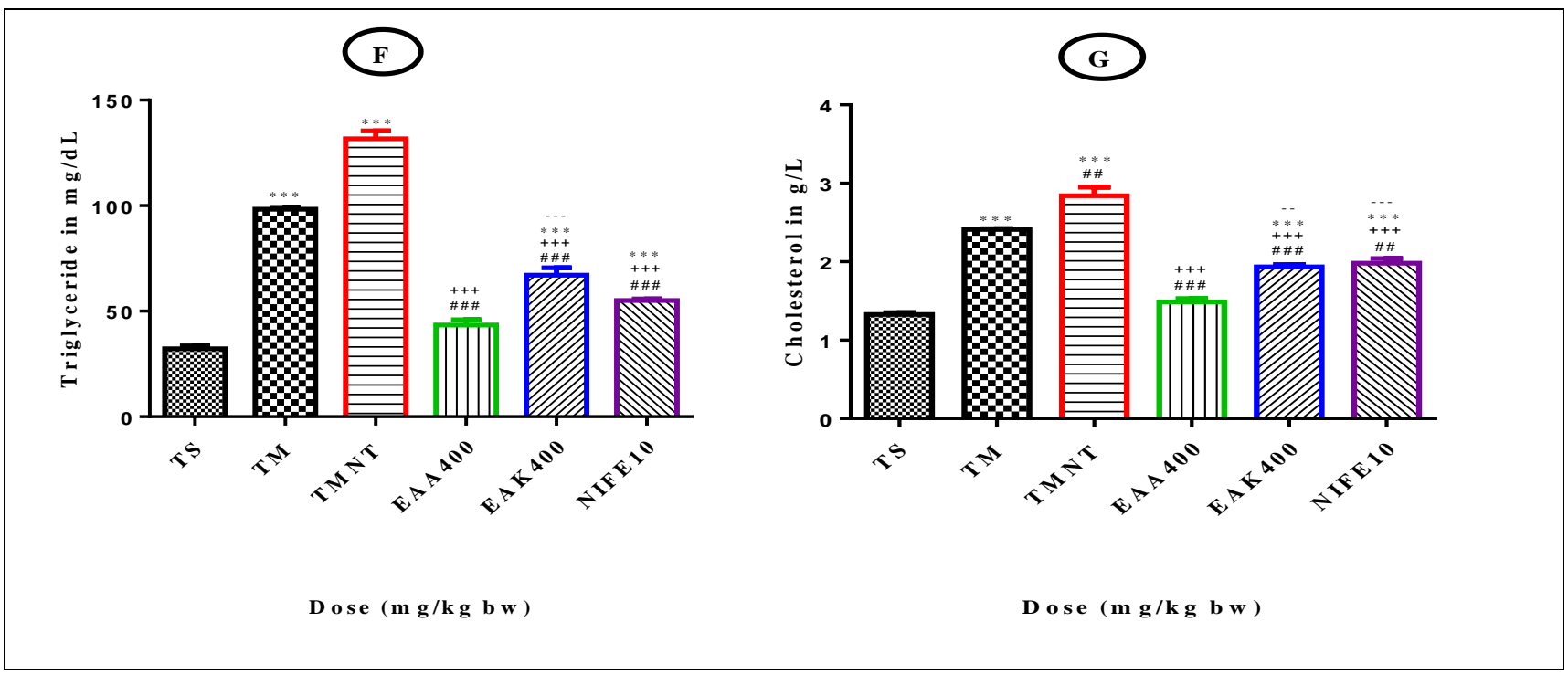

Figure 4: Comparison of the pharmacological effects of EAA and EAK extracts on serum triglyceride (F) and cholesterol $(\mathbf{G})$ values in hypertensive rats.

Each bar represents the average \pm SEM. $* * *$, significant difference from the normotensive control lot at $\mathrm{p}<0.001 ; *$ significant difference from the control lot at $\mathrm{p}<0.05$; \#\#\#, a significant difference from the hypertensive lot (TM) at $\mathrm{p}<0.001$; +++, a significant difference from the untreated diseased lot (TMNT) at $\mathrm{p}<0.001$; --- significant difference from the Adzopé Aqueous Extract (EAA) lot

TS: normotensive control lot; TM: hypertensive lot; TMNT: untreated diseased lot; EAA 400: lot treated with Adzopé Aqueous Extract at $400 \mathrm{mg} / \mathrm{kg}$ bw; EAK 400: lot treated with Korhogo Aqueous Extract at $400 \mathrm{mg} / \mathrm{kg}$ bw. 


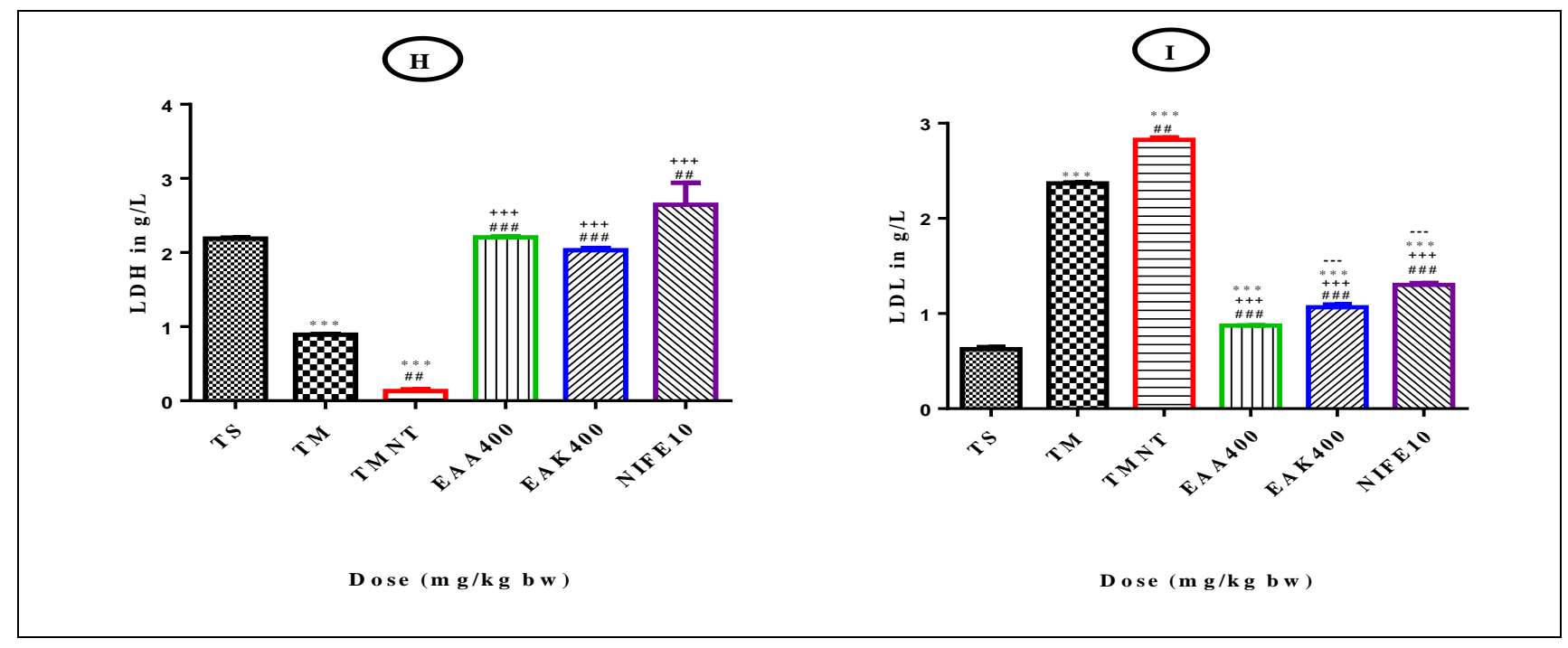

Figure 5: Comparison of Pharmacological Effects of EAA and EAK Extracts on Serum Lipoprotein Values: LDH $(\mathbf{H})$ and LDL (I) in Hypertensive Rats.

Each bar represents the average \pm SEM. $* * *$, significant difference from the normotensive control lot at $\mathrm{p}<0.001 ; *$ significant difference from the control lot at $\mathrm{p}<0.05$; \#\#\#, a significant difference from the hypertensive lot (TM) at $\mathrm{p}<0.001$; +++, a significant difference from the untreated diseased lot (TMNT) at $\mathrm{p}<0.001$; --- significant difference from the Adzopé Aqueous Extract (EAA) lot

TS: normotensive control lot; TM: hypertensive lot; TMNT: untreated diseased lot; EAA 400: lot treated with Adzopé Aqueous Extract at $400 \mathrm{mg} / \mathrm{kg} \mathrm{bw}$; EAK 400: lot treated with Korhogo Aqueous Extract at $400 \mathrm{mg} / \mathrm{kg}$ bw.

\section{Discussion}

The results of this study showed that hypertension causes a significant and permanent increase in urea, creatinine, AST, ALT, and LDH levels in diseased rats compared to healthy control rats. This increase in serum concentrations of urea and creatinine defines impairment of renal function (Bidié et al., 2016) as well as LDH, which is a marker of cardiac function, indicates myocardial injury (Coulibaly et al., 2010). Also, ALT is a hepatocyte cytosolic enzyme released into the blood in case of necrosis (Nahdi et al., 2018). Their increase in blood indicates hepatotoxicity. Thus, the high values of these enzymes observed in hypertensive rats show that hypertension affects the liver (EI Koubbaoui et al., 2017). Aqueous extracts of Blighia sapida at a dose of $400 \mathrm{mg} / \mathrm{kg}$ bw which normalizes the levels of urea, creatinine, AST, ALT, and LDH in hypertensive rats, would have a hepatic and cardioprotective effect by improving the deterioration of serum markers of the heart and liver. This action of Blighia sapida extracts can be attributed to the antioxidant compounds of the plant such as total polyphenols, flavonoids, or alkaloids. These phytocompounds can stop the increase in transaminases and serum LDH caused by the fructose diet and then reduce their concentration in the blood (Ajiboye et al., 2017). EAA extract at 400 $\mathrm{mg} / \mathrm{kg}$ bw better normalizes the increased biochemical parameters in hypertensive rats than EAK extract. This effect would be due to its high content of total polyphenols and total flavonoids. These results are in agreement with those of Nahdi et al. (2018) who reported in their study that the extract with the highest total polyphenol content has the highest therapeutic activity.

Dyslipidemia is a potential risk factor for cardiovascular disease. Our study also showed that rats had reduced HDL and significantly increased levels of total cholesterol, triglycerides, and LDL following the work of Geleta et al. (2016). According to these authors, dyslipidemia and hypercholesterolemia are associated with the pathogenesis of high blood pressure induced by the 
permanent ingestion of fructose-based diets in rats

(Geleta et al., 2016). Treatment of hypertensive rats with $400 \mathrm{mg} / \mathrm{kg}$ bw of aqueous extracts of Blighia sapida significantly $(\mathrm{P}<0.05)$ increased HDL levels and significantly reduced concentrations of total cholesterol, triglycerides, and LDL. These results show the beneficial action of aqueous extracts of Blighia sapida on lipid disorders caused by hypertension. Also, the results of Ikumawoyi et al. (2016) explained that extracts from fresh leaves and trunk bark of $Z$. zanthoxyloides significantly reduce serum concentrations of total cholesterol and LDL in rats. This antihyperlipidemic effect of Blighia sapida in hypertensive rats could be attributed to flavonoids, tannins, or saponosides. These results corroborate with those of Minato et al. (2003) and

Kolawole et al. (2007) who showed that flavonoids reduce LDL and increase HDL in hypercholesterolemic animals and the work of Bilanda et al. (2018) who showed that lipid reduction is one of how medicinal plants exert their hypotensive effect. In addition, tannins are known for their potential to reduce high levels of total cholesterol, triglycerides, and LDL and to restore serum HDL (Ravichandiran et al., 2012; Amani et al., 2016). The effect of Blighia sapida aqueous extracts on lipid disturbances caused by the fructose diet was best perceived with Adzopé aqueous extract (EAA) followed by Korhogo aqueous extract (EAK). This could be explained by the very high concentration of total flavonoids and total polyphenols in EAA extract compared to EAK extract. This difference in polyphenol and flavonoid concentrations between extracts would be due to the different climatic conditions in these areas. Indeed, the meteorological and climatic conditions such as the soil, temperature, rainfall, vegetation, and geographical area of the plant influence the synthesis and accumulation of its phytoconstituents (El Hazart et al., 2015; Allam and Ayad, 2015; Evenamede et al., 2017).

\section{Conclusion}

The present study shows that fructose consumption induces hypertension followed by an increase in serum markers of the kidney, heart, and liver and then lipid profile in rats. The treatment of animals with aqueous extracts of Blighia sapida from the South of Ivory Coast normalizes these parameters as well as possible as the aqueous extract of the same plant harvested in the North of Ivory Coast. This difference in the efficiency of the plant would be due to the different climatic conditions of the two harvesting areas of the plant. This explains the use of the plant in traditional medicine in some areas of the Ivory Coast compared to other areas where its therapeutic effects are unknown.

\section{Bibliographical references}

Ajiboye, O.T., Ahmad, M.F., Daisi, O.A., Yahaya, A.A., Ibitoye, B.O., Muritala, F.H., and Sunmonu, O.T. (2017). Hepatoprotective potential of Phyllanthus muellarianus leaf extract: studies on hepatic, oxidative stress and inflammatory biomarkers. Pharmaceutical Biology, 55 (1): 16621670 .

Allam, S., and Ayad, K. (2015). L'effet des facteurs climatiques sur la variation de quelques métabolites secondaires suivis de l'activité antibactérienne chez les deux espèces Hyoscyamus albus L. et Hyoscyamus muticus L. Mémoire de Master, 112p.

Amani, K.N., Djyh, B.N., Boga, G.L., Kouassi, K., Sévérin, K.K., N'guessan, J.D. (2016). Antihypertensive and antiatherogenic effects of Tanopati a traditional recipe used for the treatment of high blood pressure. Int $J$ Basic Clin Pharmacol;5:1903-9.

Antwi, S., Martey, O.N.K, Donkor, K., and NiiAyitey, O.L.K. (2009). Antidiarrhoeal activity of Blighia sapida (Sapindaceae) in rats and mice.

Journal of Pharmacology and Toxicology, 4: 117125.

Bidié, A.P., Yapo, A.F., Adeoti, F.M., Tiekpa, W.J., Djaman, A.J. (2016). Evaluation des effets de 
l'extrait total aqueux de chrysophyllum perpulchrum sur les marqueurs d'atteinte des reins et le profile lipidique, chez des rats rendus hypertendus a l'adrenaline. Rev. Ivoir. Sci. Technol., $28: 1-8$.

Bidié, A.P., N'Guessan, B.B., Yapo, A.F., N'Guessan, J.D. (2011). Activités antioxydantes de dix plantes médicinales de la pharmacopée ivoirienne. Sciences \& Nature, Vol. 8: 1-11.

Bilanda, D.C., Dzeufiet, D.P.D., Bopda, M.O., Kamtchouing, P., Dimo, T. (2018). Allablanckia floribunda hypotensive activity on ethanol induced hypertension in rats. J Phytopharmacol; 7(2): 146151.

Coulibaly, A., Djih, B.N., Dombia, I., Yapi, H.F. \& Djaman, A.J., (2010). Phytothérapie, 8 (6) 348 352.

Coulibaly, S.O., Ouattara, A., Ouattara, K., Coulibaly, A. (2017). Effets Antihypertensifs Des Extraits Aqueux Et Éthanolique Des Graines Fermentées De Parkia Biglobosa (Mimosaceae) Chez Les Rats. European Scientific Journal, Vol.13, No.36 ISSN: 1857 - 7881 (Print) e - ISSN 18577431.

Diehl, K-H., Hull, R., Morton, D., Pfister, R., Rabemampianina, Y., Smith, D., Vidal, J-M. and van de Vorstenbosch, C., (2001). A Good Practice Guide to the Administration of Substances and Removal of Blood, Including Routes and Volumes. J. Appl. Toxicol., 21, 15-23.

Dossou, V.M., Agbenorhevi, J.K., Combey, S., Afi-Koryoe, S., (2014). Ackee (Blighia sapida) fruit arils: Nutritional, phytochemicals and antioxidant properties. International Journal of Nutrition and Food Sciences; 3: 534-537.

El Hazzat, N, Iraqi, R, Bouseta, A. (2015). Identification par GC-MS et GCFID-O des composés volatils des olives vertes de la variété « Picholine marocaine »: effet de l'origine géographique. Int. J. Biol. Chem. Sci., 9(4) : 22192233.

El Kabbaoui, M., Chda, A., El-Akhal, J., Azdad, O., Mejrhit, N., Aarab, L., Bencheikh, R., Tazi, A. (2017). Acute and sub-chronic toxicity studies of the aqueous extract from leaves of Cistus ladaniferus L. in mice and rats. Journal of Ethnopharmacology, 209: 147-156.

Evenamede, K. S., Kpegb, K., Simalou, O., Boyode, P., Agbonon, A., Gbeassor, M. (2017). Etude comparative des activités antioxydantes d'extraits éthanoliques de feuilles, d'écorces et de racines de Cassia sieberiana. Int. J. Biol. Chem. Sci. 11(6): 2924-2935.

Fadili, K., Zerkani, H., Amadi, S., Zair, T. (2017). Etude phytochimique et evaluation de l'activité antioxydante des feuilles et des fruits du Capparis spinosa L., American journal of Innovative Research and applied Sciences, 5 (2) : 108-118

Geleta, B., Makonnen, E., Debella, A., Tadele, A. (2016). Effets antihypertenseurs et antihyperlipidémiques in vivo des extraits bruts et des fractions des feuilles Moringa stenopetala (Baker f.) Cufod. chez le rat. J. Front. Pharmacol.; 97, 1-10

Ikumawoyi, V.O., Awodele, O., Rotimi, K., Fashina, A.Y. (2016). Evaluation of the effects of the hydroethanolic root extract of zanthoxylum Zanthoxyloides on hematological parameters and oxidative stress in Cyclophospamide treated rats. Afr J Tradit Complement Altern Med. 13(5):153-159.

Kolawole, O.T., Kolawole, S.O., Ayankunle, A.A., Olaniran, O.I. (2012). Methanol leaf extract of Persea americana protects rats against cholesterolinduced hyperlipidemia. Br J Med Med Res, 2:235242.

Mamyrbékova-Békro, J.A., N'Guessan, A.H.O., Déliko, C.E.D. , Békro, Y-A. (2011). Teneurs en composés phénoliques de 10 plantes médicinales employées dans la tradithérapie de l'hypertension 
artérielle, une pathologie émergente en Côte

d'Ivoire. Revue de génie indutriel, 6: 55-61

Minato, K., Miyake, Y., Fukumoto, S., Yamamoto, K., Kato, Y., Shimomura, Y., Osawa, T. (2003). Medica flavonoid, eriocitrin, suppresses exercise-induced oxidative damage in rat liver. Life Sci, 72: 1609-1616.

Nahdi, A., Hammami, I., Ali, R.B., Kallech-Ziri, O., El May, A., El May, M.V. (2018). Effect of Hypericum humifusum aqueous and methanolic leaf extracts on biochemical and histological parameters in adult rats. Biomedicine \& Pharmacotherapy, $108: 144-152$

Okwu, D.U., Antai, A.B., Udofia, K.H., Obembe, A.O., Obasi, K.O. and Eteng, M.U. (2006). Vitamin C improves basal metabolic rate and lipid profile in alloxan-induced diabetes mellitus in rats. J. Biosci., 31 : 570-575.

Ravichandiran, V., Nirmala, S. and Ahamed, K.F.H.N., (2012). Protective effect of tannins from Ficus racemosa in hypercholesterolemia and diabetes induced vascular tissue damage in rats. Asian Pacific Journal of Tropical Medicine, 367373

Selles, C. (2012). Valorisation d'une plante médicinale à activité antidiabétique de la région de Tlemcen: Anacyclus pyrethrum L. Application de l'extrait à l'inhibition de corrosion d'un acier doux dans $\mathrm{H}_{2} \mathrm{SO}_{4}$ 0,5 M. 201 p.

Talbi, H., Boumaza, A., El-mostafa, K., Talbi, J., Hilali, A. (2015). Evaluation de l'activité antioxydante et la composition physico-chimique des extraits méthanolique et aqueux de la Nigella sativa L. (Evaluation of antioxidant activity and physico-chemical composition of methanolic and aqueous extracts of Nigella sativa L.). Mater. Environ. Sci. 6 (4) 1111-1117. 